\title{
The effect of networking behaviors on the success of entrepreneurial startups
}

\author{
Firas Albourini ${ }^{\mathrm{a}}$, Alaeddin Mohammad Khalaf Ahmad ${ }^{\mathrm{a}}$, Mohammad Abuhashesh ${ }^{\mathrm{a}}{ }^{*}$ and Nawras \\ M. Nusairat ${ }^{b}$
}

${ }^{a}$ Princess Sumaya University for Technology (PSUT), Jordan

${ }^{b}$ Applies Science University (ASU), Jordan

CH RONICLE ABSTRACT

Article history:

Received: February 16, 2020

Received in revised format:

March 272020

Accepted: March 29, 2020

Available online:

March 31, 2020

Keywords:

Entrepreneurship

Networking behaviors

Entrepreneurs' success

Jordan
Entrepreneurship is currently a popular topic for research due to the influence it brings to bear on multiple areas of life. Consequently, it is necessary to recognize the behaviors that boost the chances of entrepreneurs and their startups achieving success. This research primarily seeks to investigate the extent to which networking behaviors can influence the success of entrepreneurial startups in Jordan. For this purpose, the authors propose and study six networking behaviors as independent variables, namely cultivating internal contacts, cultivating external contacts, socialization, getting involved in professional activities, taking part in community activities, and raising one's profile within the company. The dependent variable is the success of entrepreneurial startups. A quantitative analysis was conducted by distributing a questionnaire to startup companies in Amman, Jordan. The results confirm that the better entrepreneurs are at practicing these networking behaviors, the more influence they have on the success of their startups. Those behaviors that carry most influence are cultivating internal contacts, cultivating external contacts, and getting involved in professional activities. Finally, the research recommends further study should be carried out to make known the full impact of these six networking behaviors, in addition to encouraging more wholesale adoption of entrepreneurial networking behaviors to increase the probability of success for entrepreneurial startups.

\section{Introduction}

In recent years, the focus on entrepreneurship and entrepreneurs has intensified, on both the local and global levels, since it symbolizes innovation and a dynamic economy (Hattab, 2012). Entrepreneurship holds significant value in today's economy, and has become an important issue for scholars over the past decade (Boukamcha, 2015). It can be considered as a driving force for the economy, and this impact is predicted to continue into the future, with new businesses being founded every day. Entrepreneurship offers both an opportunity for individuals who seek to become financially independent, and a solution to lessening unemployment. Successful organizations seek to hire entrepreneurial minds, because such people represent important and beneficial human resources who will make a significant impact and play a key part in the organization's success (Rathna \& Vijaya, 2009). Schumpeter (1934) asserted that an entrepreneur is one who carries out new mixes, such as formulating a new process, products, markets, sources of supply or organizational forms (Hayajneh et al., 2020). Raposo et al. (2008) set forth an historical view of an entrepreneur as being an individual who takes risks correlated with uncertainty, who can provide financial capital, a person of innovation and creativity, a decision maker; a leader of an industry; a manager, director or a supervisor; economic resources organizer and coordinator; 
a business owner; a referee; a contractor; and a locator of resources between alternative uses (Abuhashesh, 2019a). According to Kirkley (2016), those perceived to be entrepreneurial can be assigned the following attributes: independent, creative, ambitious, goal driven, risk taker, achiever, and networker (Felix et al., 2020). Studying the behaviors of entrepreneurs is a fundamental way to clarify which ones lend support to an enterprise and help it to thrive. According to Porter Gale and William Feather networking is a fundamental skill and behavior required by an individual if he/she is to acquire adequate success, which demonstrates the topic of thisresearch. Networking behaviors can be defined as the person's endeavors in cultivating relationships with other individuals who may have something to offer of benefit to his/her business enterprise. The entrepreneur takes care to network with those who may be able to promote their projects either at the present time or at some point in the future. It is worth noting that networking behaviors can impact positively on an individual's personal life, as a side benefit to the desired effect on the entrepreneur's work life (Forret \& Dougherty, 2004). Consequently, the current work seeks to answer the following question:

Q1: What is the impact of entrepreneurs' specific networking behaviors (cultivating internal contacts, cultivating external contacts, socialization, engaging in professional activities, increasing internal visibility, and participating in community activities) on the success of their entrepreneurial startups in Jordan?

\section{Literature review}

\subsection{Entrepreneurship}

Entrepreneurs and their activities are currently a hot research topic all over the world since their innovations are a major factor in energizing local markets and the world economy (Hattab, 2012). Probably the greatest hurdle in developing a theoretical model that encapsulates entrepreneurship has been the lack of consensus on its definition (Venkataraman, 1997), as, over the years, it has been defined, characterized and described differently by many people. McMullan and Long (1990) stated that entrepreneurship is when a person employs him/herself with the uncertainty of its returns. Gartner (1988) characterized entrepreneurship as the making and introduction of corporations. Upon further research, Gartner (1990) divided the meaning of entrepreneurship into two groups, the first focusing on entrepreneurial traits (creativity, growth, and uniqueness). The central point of the other group is the outcomes of entrepreneurship, such as (the delivered value). We may view entrepreneurship as the art of generating and taking advantage of an opportunity and seeking it with no regards for the currently controlled resources (McDougall \& Oviatt, 2000; Ilozor et al., 2006). For Heinonen and Poikkijoki (2006), entrepreneurship can be defined through four phases; the first is beginning to initiate a business, second is searching for an opportunity, third is evaluating and seizing the opportunity, and fourth is the success of taking advantage of that opportunity. The perspective held by Ruiz et al. (2016) is that entrepreneurship not only concentrates on establishing a firm or self-employment, but also consists of all the factors that make the business operations better and the development that makes an impact on society and adds to it a positive value. The heterogeneousness of entrepreneurship is of interest because it consequently directs our attention into various areas. This inherently means that there are a huge number of perspectives and aspects opentoresearchers wishing to study entrepreneurship, which naturally can lead to a challenge (Berglund \& Johansson, 2007).

\subsection{Entrepreneurship in Jordan}

The Global Entrepreneurship and Development Index (GEDI) score is used to measure the health of the entrepreneurship ecosystem in 132 countries on an annual basis (Acs et al., 2016). The measurement of the score is defined on a scale from 0 to 100 where 0 indicates that there is no entrepreneurship ecosystem, and 100 indicates a highly attractive entrepreneurship ecosystem. While the world's average GEDI score is 79.5 , the GEDI score for Jordan is 86.2 , an above average score which is a good indicator for the country (Acs, et al., 2016).

All but one percent of Jordan's private sector comprises businesses of small or medium size, noting that the private sector accounts for $77 \%$ of employment. The increasing number of non-profit organizations that seek to support new ideas in Jordan indicates that the encouragement of innovation is a major and essential goal within the country (Masri et al., 2010; Kanaan et al., 2020). Jordan's educational plan was modified in 2003 to develop and enhance the entrepreneurial mindset and life skills such as initiative, innovation, critical thinking, and problem-solving. In addition, students are encouraged to cultivate a creative and open mindset that has the potential to generate new ideas through endorsing entrepreneurship education with awards (Masri et al., 2010). Also, programs and services are being implemented to provide a better base and framework for future entrepreneurs in Jordan. These programs include initiatives, training courses, workshops, courses, and programs at the universities that offer degrees in business entrepreneurship. For instance, Queen Rania Center for Entrepreneurship (QRCE) regularly holds entrepreneurship events to raise the attention, consciousness, and recognition of entrepreneurship and its importance. However, educational programs about entrepreneurship have not been correctly implemented thus far in the school system (Masri, et al., 2010).

It is clear that the entrepreneurial ecosystem is receiving significant attention in Jordan. It is to be seen in multiple parties coming together to achieve financing through crowdfunding, seed funding, venture capital and micro financing. It is also evident in the media, government regulations and policies, and the existence of advisory services in the fields 
of intellectual property, business, finance and legal matters. The concept of entrepreneurship is spreading thanks to training, education, prototyping and having various supporting organizations such as incubators, accelerators, co-working space, advocacy and coaching.

\subsection{Networking}

Networking has been defined and used in various distinctive, specific and unconventional ways. For example, some researchers consider networking to refer exclusively to those external entities of the hierarchy within which the individual operates (Orpen, 1996). Our conception of what networking is can be significantly affected by the many various definitions proffered. According to Gould and Penley (1984), networking can be seen as the act of cultivating a network of contacts both within and outside the workplace, with the intention of seeking useful resources from those contacts. The researchers explained that several behaviors could be adapted to create and sustain networks, such as contacting and paying people visits, socializing prior to, during, and after official events, attending and participating in social events, mentoring, doing people favors, and holding unofficial conversations. In Orpen's (1996) opinion, networking is a functional matter, with its sphere being mainly confined to connections outside of the individual's organization. Employees could be helped in their job performance by widening their network of contacts beyond their own managers and subordinates, gaining informal cooperation from those contacts as a result. In a more recent study, Forret and Dougherty (2004) portrayed networking as the art of cultivating and sustaining useful links with other individuals who might benefit those involved in business activities in forwarding their prospects. Likewise, Wolff and Moser (2009) offered their definition of networking as "behaviors that are designed at building and maintaining informal relationships that allow access to resources and maximizing common advantages" (p. 196). From another perspective, Gulati et al. (2000) outlined the firm's external network as a "set of relationships, both vertical and horizontal with other organizations" (p. 200). Ahuja (2000) asserted that, according to the social network theory, a firm gains, attains, sustains, shares, or establishes a group of beneficial, useful and invaluable resources over its external networks, adding that such social networks present opportunities for firms to collect data, obstruct their competitors, and possibly conspire to set policies and prices. Likewise, startups can expand their networks and gain critical information and key resources from other experienced and market-savvy firms, often creating shortcuts to acquiring what they want and need, thanks to various strategic privileges and opportunities made available through the established network. Launching a startup requires rare resources, which may be embedded in the founders' or their teams' internal and external networks. An empirical research shows it is possible for newly-established enterprises to boost performance by creating strategic partnerships with external networks, which may include competitors (Zhao \& Jung, 2018; Abuhashesh, 2019b). Trustworthiness, alongside interpersonal attractiveness and relational standards bring pressure to bear on the performance of the new venture (Ferguson et al., 2016).

Startup founders, as new venture agents with the responsibility of coordinating resources, usually take advantage of their personal external networks, thus contributing an invaluable asset which has a significant value in providing the necessary resources for a successful emergence. It is a natural phenomenon for startup founders to seek out other individuals who share their passion or possess useful expertise in the field and work to build on those relationships in order to expand their knowledge or gain financial advantages. Social network theory assumes that entrepreneurs exploit their social and business contacts in the effort to promote their businesses through the creation of beneficial economic advantages. The focus of unofficial efforts lies on specific methods or network dynamics examples. This proposition has been supported by the literature (Zhao \& Jung, 2018). Some studies have suggested that word of mouth, whether positive or negative, can alter the way a marketplace operates, while others have investigated the extent to which an individual's network of contacts influences their ability to secure employment and enjoy intra-organizational mobility (Granovetter, 2005).

\subsection{Networking behaviors}

Larson and Starr (1993) indicated that the seed of entrepreneurship is the ability to seize market opportunities. Once an opportunity has been identified and the startup launched, the founder faces the challenge of competing with companies that are already well-established in the market. In the early stages, the new company faces a disadvantage due to its size (liability of smallness). In addition, the company has yet to establish its reputation and must work hard to build a corporate history (liability of newness) (Abu Zayyad et al., 2020; Michael \& Yukl, 1993). Research into the field of entrepreneurship has sought to throw light on why, despite these obvious disadvantages, a proportion of startups succeed in overcoming the odds to thrive against their competitors. Repeatedly, network theory has been suggested as a main factor for their success, with researchers pointing to the good performance of some startups being largely dependent upon the founder's personal network of useful friends, acquaintances, and business contacts (Birley, 1985; Aldrich et al., 1987; Johannisson, 1988).

The concept behind network theory is that, rather than depend on formal channels, founders can work through their network contacts to obtain a wide range of resources, whether that entails some form of knowledge or physical resources, often at a lower investment of both time and money. On occasion, they may score an advantage that would be beyond their reach in the context of regular market transactions. Dubini and Aldrich (1991) summed up this concept by 
saying that "entrepreneurs can increase their span of action through their personal networks and gain access at a limited cost to resources otherwise unavailable." (p. 308). Many researchers have found that exploiting network contacts to obtain resources offers some benefits that would not be obtained when dealing purely through market mechanisms. By observing 1902 large, stock-listed companies in the USA over a ten-year period, Jarillo (1989) discovered that those that made wise use of their external network of contacts fared better in the market than those that limited themselves to exploiting only companyowned, or internal, resources. Jarillo's (1989) study was of limited use to the present work, however, as he failed to give an accurate picture of how dealing through the network is more advantageous than purchasing resources from outside the network. Network partners may be friends or family members who are willing and able to provide the new business owner with resources at a cost lower than market price, purely out of a desire to help, or to repay a favor. A spouse or other relative may give their time for free to get the venture off the ground, or a friend with a specialized skill may offer their services at a reduced rate. For example, an entrepreneur who is setting up a clothing store needs some shelving installed and his brother, a carpenter, offers to fit the shelves for free. If the new store owner can manage to save money on a range of resources, it will inevitably give his business a boost, since his lowered costs can be passed on to customers. Competitive prices from the outset will undoubtedly attract a greater number of customers to the new venture, thus increasing its chances of success (Starr \& MacMillan, 1990). Entrepreneurs seek to benefit from networks with regard to size, positioning, and relationship structure. The larger the network, the more likely the entrepreneur is to have cheap and easy access to valuable resources and knowledge. Positioning refers to the entrepreneur's attempts to place himself within the network so that he has the shortest, most convenient route to the desired resources. The direct or indirect links between individual members of a social network is known as relationship structure (Greve \& Salaff, 2003). Forret and Dougherty (2001) set forth a networking behavior measurement scale which concentrated on the specific networking behaviors of maintaining contacts (e.g. keeping in touch via email), socializing (e.g. participating in company sports events), engaging in professional activities (e.g. attending conferences), participating in community activities (e.g. getting involved with local social groups), and increasing internal visibility (e.g. having lunch with your colleagues). Wolff and Moser (2006) offered an alternative scale, measuring networking behaviors in terms of constructing, keeping, and exploiting internal contacts, and constructing, keeping, and exploiting external contacts.

\subsection{Entrepreneurial success}

The existing literature shows little consensus with regards to the best way to determine how far a business is successful, particularly when it comes to smaller ventures. What is agreed upon is that entrepreneurial success can be presented and understood based on a group of indicators or factors. The factors can have typical economic, business, social and psychological aspects excluded or included (Fisher et al., 2014). Sefiani (2013) took survival to be a measure of success by studying the length of time for which a company is able to continue to carry out its business operations and therefore grow. Sefiani (2013) also linked success to certain characteristics of the business, such as its size, age and location, as well as a number of aspects of the individual entrepreneur's background. Financial indicators are of utmost importance to many researchers when quantifying success. However, more recently, emphasis has been shifted to non-financial factors (Walker \& Brown, 2004). Financial success can be measured by sales turnover and growth, return on investment, and profitability. Personal satisfaction and growth, skill improvement, flexible lifestyle, business longevity, customer satisfaction and retention, and career development are among the non-financial factors that can be considered (Walker \& Brown, 2004). Internal factors such as ready access to resources and the productive investment of those resources to improve profitability, as well as the ability to engage in entrepreneurial interactions, can also be taken as measures of success. Witt (2004) identified five factors for measuring entrepreneurs' success. The first is the actual establishment of the startup whereby the founder develops his/her entrepreneurial idea, forms a business plan, and launches a startup. The second factor is survival, which refers to the startup's continuity in the industry and market. Thirdly, we see subjective evaluation, or what the person feels and expects about being an entrepreneur, while the fourth factor involves profits. The startup can be considered successful when it is making a profit and giving return on investment. The final factor is growth rate which focuses on the number of employees within the firm, and market share size (Booth et al., 2020). For Ridzwan et al., (2017), success can be measured through the company's continuity and growth rate, introduction of new products or business practices, profitability, the level of satisfaction among the owner, employees and other stakeholders, work-life balance, the extent to which the public recognizes its social and environmental performance, as well as its ongoing relevance to the market. The authors of this research have sought to use the most comprehensive and relevant measures of success, having selected them from various scales in the reviewed literature. The chosen measurements for entrepreneurial success are: Actual foundation (Witt, 2004); profitability (Ridzwan et al., 2017; Witt, 2004; Walker \& Brown, 2004); growth (market share and people employed) (Ridzwan et al., 2017; Sefiani, 2013; Witt, 2004; Walker \& Brown, 2004); innovation, satisfaction of the stakeholders, public recognition, utility or usefulness (Ridzwan et al., 2017); and work-life balance (Ridzwan et al., 2017; Walker \& Brown, 2004). For the purpose of this research, the following sub-hypotheses have been derived from the literature:

$\mathrm{H}_{1 \mathrm{~A}}$ : Cultivating internal contacts has a positive impact on the success of entrepreneurial startups. Cultivating internal contacts positively influences the success of entrepreneurial startups.

$\mathrm{H}_{1 \mathrm{~B}}$ : Cultivating external contacts has a positive impact on the success of entrepreneurial startups. Cultivating external contacts positively influences the success of entrepreneurial startups.

$\mathrm{H}_{1 \mathrm{C}}$ : Socialization has a positive impact on the success of entrepreneurial startups. Socialization positively influences 
the success of entrepreneurial startups.

$\mathrm{H}_{1 \mathrm{D}}$ : Engaging in professional activities has a positive impact on the success of entrepreneurial startups. Getting involved in professional activities positively influences the success of entrepreneurial startups.

$\mathrm{H}_{1 \mathrm{E}}$ : Increasing internal visibility has a positive impact on the success of entrepreneurial startups. Increasing internal visibility positively influences the success of entrepreneurial startups.

$\mathrm{H}_{1 \mathrm{~F}}$ : Participating in community activities has a positive impact on the success of entrepreneurial startups. Taking part in community activities positively influences the success of entrepreneurial startups.

\subsection{Contribution to literature}

Sometimes it is advantageous for a business person to mine their network of contacts in an effort to obtain knowledge and resources that are difficult to reach through official channels. It was evident from the research that the number and diversity of contacts had a bearing on an entrepreneur's success (Witt, 2004). A positive connection between networking and various company performance indicators was a recurring theme in the literature (Duchesneau \& Gartner 1990; Zhao \& Aram, 1995). Greve and Salaff (2003) investigated the role of networking activities of entrepreneurs, and found that social relations (networks) are of great influence when launching a startup. In his study, Witt (2004) investigated the measures of entrepreneurial networks and their impact on the success of startups, yet those measures were limited to actions designed to make and retain contacts, the framework of networks already in place, and the resources that were being gained through members of the network. The benefits to startup owners of maintaining a lively entrepreneurial network and the ultimate success of their venture were evident from the study results. Forret and Dougherty (2004) studied networking behaviors and found a positive relation between them and career outcomes. The literature also shows that networks can be an important factor for achieving the desired outcomes for any enterprise. A business owner's capacity for exploring their contacts and reaching out to members of other organizations may be instrumental in bringing about the success they seek (Hoyos-Ruperto et al., 2013). In a study conducted in the Moroccan city of Tangier, Sefiani (2013) found that networking positively influences the success of small and medium businesses. The academic contribution of this research lies in its focus on the role and impact of entrepreneurs' specific networking behaviors on the entrepreneurial startups' success in a unique manner in Jordan (Abuhashesh, 2019c).

\section{Methodology}

\subsection{Research Population and Sampling}

As the study seeks to understand and evaluate the impact of networking behaviors on the success of entrepreneurial startups in Jordan, the population of this study comprises entrepreneurs running their businesses in Jordan. Field visits were conducted to various business accelerators in Jordan and information was gathered from entrepreneurs, using the purposive sampling method. Out of a total of 300 distributed questionnaires, 162 were correctly completed and sent back, a percentage of (54\%). Entrepreneurs were chosen across different industrial sectors. The researchers knew some of the participants through personal connections or via word of mouth, while others were identified through social media accounts, business accelerators, online journals that list entrepreneurs and foundations that support and have interest in entrepreneurs and entrepreneurial initiatives in Jordan.

\subsection{Research model}

The authors' examination of the previous studies led to the development of the following research model which is composed of the independent variables (Networking behaviors). These variables were studied independently and linked to the dependent variable (Success of entrepreneurial startups). Fig. 1 illustrates this model.

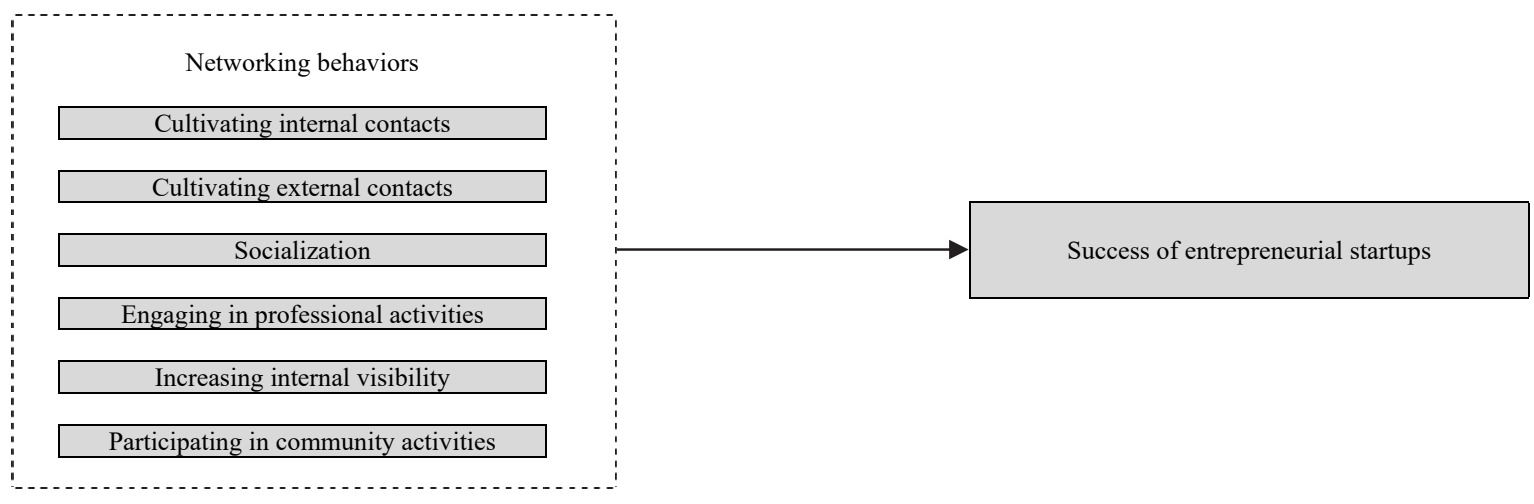

Fig. 1. Research Model 


\subsection{The Research Tool}

The research used a quantitative approach, due to the fact that is there is previous knowledge supplied by studies conducted on the topic, and the aim of this study is to investigate and generalize the hypothesis that there is a relationship between those variables. The chosen study tool takes the form of a questionnaire, which was developed after due consideration and selection of the related and suitable studies and measuring tools from the literature in order to develop a questionnaire that covers all the variables. The independent variables are the networking behaviors (cultivating internal contacts, cultivating external contacts, socializing, getting involved in professional activities, increasing internal visibility, taking part in community activities). The dependent variable is the measurement of success of the startups. This study formulated an online survey using Google forms and a printed version.

\subsection{Research Tool Reliability}

Table (1) shows Cronbach's alpha values, which were used to determine the internal consistency reliability of the elements. Reliability should be $(0.60)$ or higher to indicate adequate convergence or internal consistency (Sekaran $\&$ Bougie, 2016). Cronbach's alpha coefficients of all the tested variables are above 0.60 , which reveals the reliability of the composite measure.

Table 1

Reliability of the Questionnaire's Dimensions

\begin{tabular}{|c|c|c|c|c|}
\hline & & & No. of Items & Cronbach's Alpha Value \\
\hline \multirow[t]{7}{*}{1} & \multicolumn{2}{|c|}{ Networking Behaviors } & 29 & $76.8 \%$ \\
\hline & 1 & Cultivating internal contacts & 5 & $70.6 \%$ \\
\hline & 2 & Cultivating external contacts & 5 & $70.1 \%$ \\
\hline & 3 & Socialization & 5 & $73.1 \%$ \\
\hline & 4 & Engaging in professional activities & 6 & $75.4 \%$ \\
\hline & 5 & Increasing internal visibility & 4 & $72.6 \%$ \\
\hline & 6 & Participating in community activities & 10 & $85.5 \%$ \\
\hline \multirow[t]{2}{*}{2} & \multicolumn{2}{|c|}{ Success of Entrepreneurial Startups } & 10 & $85.5 \%$ \\
\hline & \multicolumn{2}{|c|}{ All Questionnaires } & 39 & $86.3 \%$ \\
\hline
\end{tabular}

\subsection{Normal Distribution of Study Variables}

The Kolmogorov - Smirnov Test was conducted in order to ascertain that the data collected is free of statistical problems that influence the results of the test study hypotheses in a negative fashion, as can be seen in Table 2.

Table 2

Normal Distribution of Study Variables

\begin{tabular}{|c|c|c|c|c|}
\hline No. & Variables & Kolmogorov-Smirnov & Sig.* & Result \\
\hline 1 & Networking Behaviors & 1.110 & 0.170 & Follows a normal \\
\hline $1-1$ & Cultivating internal contacts & 1.183 & 0.122 & Follows a normal \\
\hline $1-2$ & Cultivating external contacts & 1.264 & 0.082 & Follows a normal \\
\hline $1-3$ & Socialization & 0.940 & 0.340 & Follows a normal \\
\hline $1-4$ & Engaging in professional activities & 1.001 & 0.269 & Follows a normal \\
\hline $1-5$ & Increasing internal visibility & 0.910 & 0.379 & Follows a normal \\
\hline \multirow[t]{2}{*}{$1-6$} & Participating in community activities & 0.903 & 0.338 & Follows a normal \\
\hline & Success of entrepreneurial startups & & & a normal distribution \\
\hline
\end{tabular}

Distribution is normal when the significance level $(\alpha>0.05)$.

Upon examining Table 2 and finding that the significance level stands at $(\alpha>0.05)$, it is evident that there was a normal distribution of variables across the board. The normal distribution ratios for each variable exceeded $(0.05)$, and are therefore acceptable for the statistical treatment of the study in hand.

\section{Results}

\subsection{Descriptive Analysis}

In order to make the data meaningful, descriptive information including means and standard deviations were analyzed on the variables measured in this research.

\subsection{Descriptive Analysis}

The mean score of the total networking behaviors is 3.09 with a standard deviation at 0.468 , while descriptive information for every networking behavior factor ascends as follows: Increasing internal visibility 3.67 (SD 0.667); Cultivating external contacts 3.26 (SD 0.711); Cultivating internal contacts 3.25 (SD 0.748); Participating in community activities 3.21 (SD 0.857); Socialization 2.77 (SD 0.789); and Engaging in professional activities 2.60 (SD 0.530). The levels for 'Increasing internal visibility' are high, standing at above 3.66, while the remaining dimensions' levels are medium. Regarding the dependent dimension, the mean score of the total success of entrepreneurial startups was 3.28 with a standard deviation at 0.542 . 
Table 3

Means and Standard Deviations of Networking Behaviors Dimensions

\begin{tabular}{|c|c|c|c|c|c|}
\hline No & Dimensions & Mean & $\mathrm{SD}$ & Severity & Rank \\
\hline 1 & Cultivating internal contacts & 3.25 & 0.748 & Medium & 3 \\
\hline 2 & Cultivating external contacts & 3.26 & 0.711 & Medium & 2 \\
\hline 3 & Socialization & 2.77 & 0.789 & Medium & 5 \\
\hline 4 & Engaging in professional & 2.60 & 0.530 & Medium & 6 \\
\hline 5 & Increasing internal visibility & 3.67 & 0.667 & High & 1 \\
\hline \multirow[t]{3}{*}{6} & Participating in community activities & 3.21 & 0.857 & Medium & 4 \\
\hline & Networking behaviors & 3.09 & 0.468 & & \\
\hline & Success of entrepreneurial startups & 3.28 & 0.542 & & \\
\hline
\end{tabular}

\subsection{Multicollinearity Diagnostics}

Prior to the hypotheses testing for the study, some tests were conducted to make sure the data was adequate for the assumptions of regression analysis. As a result, no high correlation was identified between the independent variables multicollinearity using the Variance Inflation Factor (VIF) and test Tolerance for each variable, taking into account the Variance Inflation factor is not to exceed the allowable value (10), and that the tolerance value must be greater than (0.05). It was also ensured that the data follows the normal distribution calculating the skewness coefficient, knowing that the data follows a normal distribution if the value of skewness coefficient is less than $( \pm 1)$. The test results can be seen in Table 4 .

Table 4

Results of Variance Inflation Factor, Tolerance and Skewness Coefficient

\begin{tabular}{|c|c|c|c|c|}
\hline No. & Independent Variables & VIF & Tolerance & Skewness \\
\hline 1 & Cultivating internal contacts & 4.696 & 0.213 & -0.319 \\
\hline 2 & Cultivating external contacts & 4.951 & 0.202 & -0.258 \\
\hline 3 & Socialization & 1.471 & 0.680 & -0.312 \\
\hline 4 & Engaging in professional activities & 1.321 & 0.757 & .4750 \\
\hline 5 & Increasing internal visibility & 1.662 & 0.602 & 0.146 \\
\hline 6 & Participating in community activities & 1.432 & 0.698 & -0.207 \\
\hline
\end{tabular}

It is evident from the results listed in Table 4 that no multicollinearity exists between the independent variables, a fact which is backed up by the values of Variance Inflation Factor of the dimensions, specifically $(4.696,4.951,1.471,1.321,1.662$, and 1.432) respectively, which are all values below (10). It is clear that the values of Tolerance exceed (0.05), ranging between $(0.146-0.475)$, thus indicating a lack of multicollinearity between the independent variables. In order to ensure that the data follows a normal distribution, the researchers calculated the Skewness coefficient where the values were less than $( \pm 1)$.

\subsection{Research Hypotheses Test}

$\mathbf{H}_{1}$ : Networking behaviors (“cultivating internal contacts", "cultivating external contacts", "socialization", "engaging in professional activities", "increasing internal visibility", and "participating in community activities") have a positive impact on the success of entrepreneurial startups. A simple linear regression test was conducted to investigate the H1A-H1F hypothesis. The results of the test are shown in Table (5). From the Table, $\mathrm{R}$ value represents simple correlation and is $(0.313)$, which indicates that the relationship between two variables is generally considered a good impact size. The $\mathrm{R}^{2}$ value indicates how much of the total variation in the success of entrepreneurial startups can be explained by networking behaviors. In this case, $(9.8 \%)$ can be explained; while the remaining proportion $(90.2 \%)$ can be explained by other variables that are not included in the regression model. An ANOVA table provides an F-test to determine whether the model is a good fit for the data. According to this p-value, it is. Since F $(1,160$ degree of freedom $)=(17.369, p \leq 0.05)$, this indicates that, overall, the regression model is statistically significant (a good fit for the relationship between networking behaviors and success of entrepreneurial startups). The Coefficients table provides the necessary information to predict the success of entrepreneurial startups from various networking behaviors, as well as to determine whether networking behaviors contribute statistically significantly to the model. Besides, Beta values for networking behaviors reached ( 0.313$)$ which indicates that (31.3\%) of the success of entrepreneurial startups may be predicted from networking behaviors. In other words, the results can be interpreted as (For every unit increase in networking behaviors, there is a prediction of $31.3 \%$ unit increase in the success of entrepreneurial startups). The results indicate that we should reject the null hypothesis and accept the alternative hypothesis.

Table 5

Simple Linear Regression Analysis to Ensure the Impact of Networking Behaviors on the Success of Entrepreneurial Startups

\begin{tabular}{cccccccccc}
\hline $\begin{array}{c}\text { Dependent } \\
\text { Variable }\end{array}$ & \multicolumn{2}{c}{ Model Summary } & \multicolumn{3}{c}{ ANOVA } & \multicolumn{2}{c}{ Coefficient } \\
\cline { 2 - 7 } & $\mathrm{R}$ & $\mathrm{R} 2$ & $\mathrm{~F}$ & $\mathrm{df}$ & Sig. & $\mathrm{t}$ & Sig. \\
\hline Success of entrepreneurial startups & 0.313 & 0.098 & 17.369 & 1 & 0.000 & 0.313 & 4.168 & 0.000 \\
\hline
\end{tabular}

This main hypothesis included six sub-hypotheses 
$\mathrm{H}_{1 \mathrm{~A}}$ : Cultivating internal contacts has a positive impact on the success of entrepreneurial startups.

$\mathrm{H}_{1 \mathrm{~B}}$ : Cultivating external contacts has a positive impact on the success of entrepreneurial startups.

$\mathrm{H}_{1 \mathrm{C}}$ : Socialization has a positive impact on the success of entrepreneurial startups.

$\mathrm{H}_{1 \mathrm{D}}$ : Engaging in professional activities has a positive impact on the success of entrepreneurial startups.

$\mathrm{H}_{1 \mathrm{E}}$ : Increasing internal visibility has a positive impact on the success of entrepreneurial startups.

$\mathrm{H}_{1 \mathrm{~F}}$ : Participating in community activities has a positive impact on the success of entrepreneurial startups.

The researchers tested this hypothesis by using the multiple regression analysis to measure the impact of networking behaviors dimensions (Cultivating internal contacts, cultivating external contacts, socialization, getting involved in professional activities, increasing internal visibility, and taking part in community activities) on the success of entrepreneurial startups. Table 6 illustrates the results.

Table 6

Multiple Regression Analysis to Ensure the Impact of Networking Behaviors Dimensions on the Success of Entrepreneurial Startups

\begin{tabular}{|c|c|c|c|c|}
\hline Dependent Variable & $\mathrm{B}$ & & $\mathrm{T}$ & Sig* \\
\hline \multirow{6}{*}{ Success of Entrepreneurial Startups } & Cultivating internal contacts & 0.376 & 2.416 & 0.017 \\
\hline & Cultivating external contacts & 0.453 & 2.836 & 0.005 \\
\hline & Socialization & 0.151 & 1.729 & 0.086 \\
\hline & Engaging in professional activities & 0.184 & 2.235 & 0.027 \\
\hline & Increasing internal visibility & 0.144 & 1.553 & 0.123 \\
\hline & Participating in community activities & 0.157 & 1.833 & 0.069 \\
\hline
\end{tabular}

*The impact is significant at level $(\alpha \leq 0.05) . \mathrm{F}=6.49(0.000) \mathrm{R}$-Square $=0.201$

Table 6 shows the impact of networking behaviors (Cultivating internal contacts, cultivating external contacts, socialization, getting involved in professional activities, increasing internal visibility, and taking part in community activities) on the success of entrepreneurial startups. The regression model achieved a high degree of fit, as reflected by $(R)$ and $\left(R^{2}\right)$ value $(0.448)$ , (0.201), which asserted that $(20.1 \%)$ of the explained variation in success of entrepreneurial startups can be accounted for by networking behaviors (cultivating internal contacts, cultivating external contacts, getting involved in professional activities). On the other hand, Table (6) for the executive data set indicated the slope value of $(0.376),(0.453)$ and $(0.184)$ for the regression line. This suggested that for a one unit increase in networking behaviors (cultivating internal contacts, cultivating external contacts, getting involved in professional activities) we can significantly predict a $(37.6 \%),(45.3 \%)$ and $(18.4 \%)$ increase in success of entrepreneurial startups. Additionally, it is clear from Table (6) that the analysis of variance of the fitted regression equation is significant with $\mathrm{F}$ value of (6.490), thus demonstrating the suitability of the model. Since the p-value is less than (0.05), it shows a statistically significant relationship between the variables at (0.95) confidence level. Evidently, the networking behaviors ("cultivating internal contacts", "cultivating external contacts", "getting involved in professional activities") actually impact on the success of entrepreneurial startups with a coefficient of (0.376) for "cultivating internal contacts", $(0.453)$ for "cultivating external contacts" and $(0.184)$ for "getting involved in professional activities". Thus, we can conclude that these three networking behaviors do indeed impact on the success of entrepreneurial startups. The first null hypothesis is rejected and the alternative hypothesis accepted:

Networking behaviors ("cultivating internal contacts", "cultivating external contacts", "getting involved in professional activities") influence the success of entrepreneurial startups in a positive way.

\section{Discussion of the results}

For the main hypothesis, a linear regression test was conducted. Simple correlation is represented by the $\mathrm{R}$ value, standing at (0.313). This value points to a considerable impact size between two variables and calls for the rejection of the null hypothesis and the acceptance of the alternative hypothesis. As a result, there exists a considerable statistical impact for the networking behavior on the success of the entrepreneurial startups. The results are aligned and in harmony with the existing literature on the topic. A study concludes that the extent to which a startup enterprise achieves success, however subjectively measured, increases at a proportional rate with the extent to which enterprise founders seek to benefit from their network partners. A similar positive relation exists between startup success and the entrepreneur's efforts to gain resources via his/her network contacts. In addition to his/her formal qualifications and experience, the startup owner's intentions bring direct influence to bear on the success of the enterprise when success is measured by profit margins, the ability of the startup to expand, and value creation (Witt, 2004). Noting that the networking behaviors under focus in our research were heavily influenced by those in a study by (Forret \& Dougherty, 2004), we can measure and compare the results of our research on entrepreneurs and their startups' success with their study on the effect of the networking behaviors of individuals, managers, and professionals on career success, and conclude the 
following: Hypothesis H1E of our study asserts that one way of boosting career success is by increasing internal visibility. An individual can achieve this by taking on high profile tasks within the workplace, getting involved with official team efforts to improve the efficiency of the enterprise, and/or contributing innovative ideas that will introduce new services or products. All of these offer opportunities for managers and professionals to raise their profile in the organization. One would consider that a solid performance in these roles should be rewarded with increased monetary compensation as well as recognition of their success, and such individuals should be perceived as successful in their careers (Forret \& Dougherty, 2004). The same concept can be applied to entrepreneurs and their internal visibility and recognition within their startups, which can be reflected directly or indirectly in their success. In the same study, engaging in professional activities was related to career success in the multiple regression analysis, which may be explained by the fact that participation in professional activities makes individuals visible and open to receiving more lucrative employment opportunities (Forret \& Dougherty, 2004). This can be translated in our study as the recognition of the entrepreneur internally and externally, which creates the opportunity for him/her create relationships with people of influence in the same or other organizations who may pave the way to partnerships, investments, connections, and knowledge, and thus increasing the chances that their startup ultimately succeeds. This lends support to hypothesisH1D.

The same study states that socializing has a somewhat less important impact on career success. Taking part in social activities, such as company quiz nights or sporting events, may promote a feeling of perceived success as the individual feels that he/she occupies a valued place in the organization (Forret \& Dougherty, 2004). This can be translated in our study to building a sense of belonging for the entrepreneur and their employees, thus increasing their loyalty to the business and ecosystem. These activities can lead to the success of the entrepreneur and the startup, which is translated into hypothesis $\mathrm{H} 1 \mathrm{C}$.

In the same study, building and retaining a large circle of contacts outside the organization was seen to boost career success (Forret \& Dougherty, 2004), which is aligned to one of the most influential variables in this study, which is translated into hypothesis H1B. As a contribution, this behavior was extended to cover not only maintaining external contacts, but also building and using those contacts. These behaviors have been merged together under the concept "cultivating external contacts". The same concept has been implemented to study the influence of cultivating internal contacts covered by hypothesis H1A.

Previous studies have looked at the behaviors that are beneficial to employees in boosting their careers and bringing about their success. This study serves to apply those behaviors to entrepreneurs and to condition their behaviors to lead to entrepreneurial success. The study suggests that networking behaviors have a positive impact on the entrepreneurial success for startups. Consequently, we can report that the findings of this study are in harmony with those that preceded it. Sefiani (2013) studied the extent of networking as a significant factor of business success among small enterprises in Tangier, Morocco, and found that the existence of 'wasta', a common concept in Arab countries, gives a different perspective of networking as opposed to Western concepts. Wasta is translated into a "middleman" or "favoritism" - the practice among those with power or influence of preferring friends or relatives, specifically by giving them jobs even though when they are not qualified (OxfordDictionaries.com). Understanding the concept of 'wasta' can be of great importance to non-Arab managers of the numerous international companies operating in Tangier, giving them a better grasp on culture-specific networking in that part of the world. Sefiani's research is pertinent to the current study as the concept of 'wasta' is a prevailing one in Jordan.

\section{Conclusion}

The growing attention and support given to entrepreneurship at both the national and global levels make itan important phenomenon. As such, it is crucial that the topic receive serious consideration in terms of studying and analyzing the factors, reasons and behaviors that impact and lead to the success of certain entrepreneurial ventures. For this reason, this study examines the impact of networking behaviors on the success of entrepreneurial startups in Jordan. By understanding the possible impact, entrepreneurs can ensure that they are practicing the behaviors that are more likely to bring about the success of their entrepreneurial startups. The results of this study show that networking behaviors, especially those of cultivating internal contacts, cultivating external contacts, and getting involved in professional activities, do indeed promote the success of entrepreneurial startups in Jordan. These results are fully aligned with those of other studies on related topics. Consequently, it can be suggested to entrepreneurs that networking behaviors are a key to be considered and effectively adopted by those who are seeking the success of a startup enterprise in Jordan. The results also show that demographics, which are represented by gender, age, work experience, and education level, fail to affect any significant statistical impact on the success of entrepreneurial startups.

\section{Recommendations}

The results of this research prompt a number of recommendations. As the entrepreneurial ecosystem is evidentlyagrowing sector in Jordan, it is recommended that focus be given to the success factors and entrepreneurial behaviors that lead to success. Also, since networking behaviors have a significant statistical impact on the success of entrepreneurial startups, 
it is recommended to go further and study additional networking behaviors, and investigate their impact on entrepreneurial success. Moreover, it is recommended to study the influence of demographics on networking behaviors and, in turn, their impact on entrepreneurial success.

On a professional level, since networking behaviors have been shown to have a significant statistical impact on the success of entrepreneurial startups, it is recommended that entrepreneurs adopt these behaviors to increase the chances that their businesses succeed. In order to raise awareness, it is recommended that incubators, accelerators and trainers in the entrepreneurship ecosystem organize workshops to focus on how to build networks of connections for individuals with entrepreneurial aspirations. Since cultivating external contacts proved to be the variable with the highest impact on the success of entrepreneurial startups, it is recommended that entrepreneurs in Jordan focus on it. Such behaviors include keeping in touch with contacts via phone or social media, ensuring that those who have provided some resources receive a token of appreciation, taking contacts from outside the company for a meal, sending good wishes and regards via mutual acquaintances to business contacts outside the company, and getting together with business associates to swap professional expertise. Entrepreneurs should also focus on cultivating both internal and external contacts by participating in or attending professional workshops or seminars, giving public talks about their professional experiences, writing for newspaper or magazines, making television appearances, and presenting articles for any publications that represent the company. In order to perform any of these functions, the individual is obliged to strengthen contacts within the organization in order to gather the necessary information, and then network with those outside the company who can facilitate the dissemination of the information.

\section{Research Limitations}

Of the limitations that the authors met while conducting this study, the first were of a geographic nature. The study was confined to the capital city of Jordan, Amman, due to the relatively high density of entrepreneurial startups to be found there. In order to make a comprehensive study possible and enable a generalization of results, the study must be widened to cover the remaining cities of the country if one is to get a comprehensive reading of the state of the entrepreneurial sector in the Kingdom. There were also some limitations posed by the small sample size. The study analyzed 162 completed quantitative filled questionnaires. It is desirable to increase the sample size in further studies to enable researchers to get a better scope and yield more accurate results.

\section{References}

Abuhashesh, M., Al-Khasawneh, M., Al-Dmour, R., \& Masa'deh, R. (2019a). The impact of Facebook on Jordanian consumers' decision process in the hotel selection. IBIMA Business Review, 1-16.

Abuhashesh, M., Al-Dmour, R., \& Masa'deh, R. (2019b). Factors that affect Employees Job Satisfaction and Performance to Increase Customers' Satisfactions. Journal of Human Resources Management Research, 1-23.

Abuhashesh, M., Mohammad, S. J., \& Khasawneh, M. A. (2019c). The attitude of Jordanian customers towards virtual stores. International Journal of Islamic Marketing and Branding, 4(1), 59-75.

Acs, Z. J., Szerb, L., and Autio, E. (2016). The global entrepreneurship and development index. In Global Entrepreneurship and Development Index 2014 (pp. 39-64). Springer International Publishing.

Ahuja, G. (2000). "Collaboration networks, structural holes, and innovation: a longitudinal study". Administrative Science Quarterly, 45(3), 425- 455.

Aldrich, H. E., Rosen, B., \& Woodward, B. (1987). The impact of social networks on business foundings and profit: a longitudinal study. Frontiers of Entrepreneurship Research, 154-168.

Berglund, K., \& Johansson, A. W. (2007). Constructions of entrepreneurship: A discourse analysis of academic publications. Journal of Enterprising Communities: People and Places in the Global Economy, 1(1), 77-102.

Birley, S. (1985). The role of networks in the entrepreneurial process. Journal of Business Venturing, 1, $107-117$.

Booth, P., Chaperon, S. A., Kennell, J. S., \& Morrison, A. M. (2020). Entrepreneurship in island contexts: A systematic review of the tourism and hospitality literature. International Journal of Hospitality Management, 85, 102438.

Boukamcha, F. (2015). Impact of training on entrepreneurial intention: an interactive cognitive perspective. European Business Review, 27(6), 593-616.

Dubini, P. \& Aldrich, H. E. (1991). Personal and extended networks are central to the entrepreneurial process. Journal of Business Venturing, 6, 305-313.

Duchesneau, D. A., \& Gartner, W. B. (1990). A profile of new venture success and failure in an emerging industry. Journal of Business Venturing, 5(5), 297- 312.

Ferguson, R., Schattke, K., \& Paulin, M. (2016). The social context for value co-creations in an entrepreneurial network: influence of interpersonal attraction, relational norms and partner trustworthiness. International Journal of Entrepreneurial Behavior and Research, 22(2), 199-214.

Felix, C., Aparicio, S., \& Urbano, D. (2020). Entrepreneurial Leadership Across Countries: The Role of Informal Institutions. In Entrepreneurship and Family Business Vitality (pp. 67-83). Springer, Cham.

Fisher, R., Maritz, A., \& Lobo, A. (2014). Evaluating entrepreneurs' perception of success. International Journal of Entrepreneurial Behavior and Research, 20(5), 478-492. 
Forret, M. L., \& Dougherty, T. W. (2001). Correlates of networking behavior for managerial and professional employees. Group and Organization Management, 26(3), 283-311.

Forret, M. L., \& Dougherty, T. W. (2004). Networking behaviors and career outcomes: Differences for men and women? Journal of Organizational Behavior, 25(3), 419-437.

Gartner, W. B. (1988). "Who is an entrepreneur?" is the wrong question. American Journal of Small Business, 12(4), 11-32.

Gartner. W. B. (1990). What are we talking about when we talk about entrepreneurship? Journal of Business Venturing, 5 , $15-28$.

Gould, S., \& Penley, L.E. (1984). Career strategies and salary progression: a study of their relationships in a municipal bureaucracy. Organizational Behavior and Human Performance, 34(2), 244-265.

Granovetter, M. (2005). The impact of social structure on economic outcomes. The Journal of Economic Perspectives, 19(1), $33-50$.

Greve, A., \& Salaff, J. (2003). Social networks and entrepreneurship. Entrepreneurship Theory and Practice, 28(1), 1-22.

Gulati, R., Nohria, N., \& Zaheer, A. (2000). Guest editors' introduction to the special issue: strategic networks. Strategic Management Journal, 21(3), 199-201.

Abu Zayyad, H. M., Obeidat, Z. M., Alshurideh, M. T., Abuhashesh, M., Maqableh, M., \& Masa’deh, R. E. (2020). Corporate social responsibility and patronage intentions: The mediating effect of brand credibility. Journal of Marketing Communications, 1-24.

Hattab, H. (2012). Towards understanding female entrepreneurship in Middle Eastern and North African countries. Education, Business and Society: Contemporary Middle Eastern Issues, 5(3), 171-186.

Ilozor, B., Sarki, A., Hodd, M., Heinonen, J., \& Poikkijoki, S. A. (2006). An entrepreneurial-directed approach to entrepreneurship education: mission impossible?. Journal of Management Development, 25(1), 80-94.

Hayajneh, N., Suifan, T., Obeidat, B. Y., Abuhashesh, M., \& Kanaan, R. K. (2020). The relationship between organizational changes and job satisfaction in the Jordanian telecommunication industry. Journal of Social Sciences (COES\&RJJSS), 9(1), 1-20.

Hoyos-Ruperto, M., Romaguera, J., Carlsson, B., \& Lyytinen, K. (2013). Networking: A critical success factor for entrepreneurship. American Journal of Management, 13(2), 2013

Jarillo, J. C. (1989). Entrepreneurship and growth: the strategic use of external resources. Journal of Business Venturing, 4, $133-147$.

Johannisson, B. (1988). Business formation - a network approach. Scandinavian Journal of Management, 4, 83-99.

Kirkley, W. W. (2016). Entrepreneurial behaviour: the role of values. International Journal of Entrepreneurial Behavior \& Research, 22(3), 290-328.

Larson, A., \& Starr, J. A. (1993). A network model of organization formation. Entrepreneurship theory and practice, 17(2), 5-15.

Masri, M., Jemni, M., \& Al-Ghassani, A. (2010). Entrepreneurship education in the Arab States: a joint project of UNESCO and the StratREAL Foundation, United Kingdom: case studies of the Arab States (Jordan, Tunisia, Oman, Egypt) and regional synthesis report.

McDougall, P. P., \& Oviatt, B. M. (2000). International entrepreneurship: the intersection of two research paths. Academy of Management Journal, 43(5), 902-906.

McMullan, W. E., \& Long, W. A. (1990). Developing new ventures: The entrepreneurial option. Harcourt Brace Jovanovich.

Michael, J., \& Yukl, G. (1993). Managerial level and subunit function as determinants of networking behavior in organizations. Group \& organization management, 18(3), 328-351.

Orpen, C. (1996). Dependency as a moderator of the effects of networking behavior on managerial career success. The Journal of Psychology, 130(3), 245-248.

Solomon, G., Raposo, M., do Paço, A., \& Ferreira, J. (2008). Entrepreneur's profile: a taxonomy of attribu tes and motivations of university students. Journal of Small Business and Enterprise Development, 15(2), 405-418.

Rathna, K. G., \& Vijaya, T. G. (2009). Competencies of entrepreneurs and intrapreneurs: A comparative study. South Asian Journal of Management, 16(2), 28.

Ridzwan, R., Muhammad, N. M. N., \& Ab Rahman, A. A. (2017). Exploring Model of Entrepreneurship Success: A Summary Review of the Literature. Saudi Journal of Business and Management Studies, 2(3), 270-277

Ruiz, J., Soriano, D. R., \& Coduras, A. (2016). Challenges in measuring readiness for entrepreneurship. Management Decision, 54(5), 1022-1046.

Kanaan, R. K., Obeidat, U. N., Obeidat, B. Y., Al-Zu'bi, M. O., \& Abuhashesh, M. (2020). The Effect of Intellectual Capital on Competitive Advantage in the Jordanian Telecommunication Sector. Journal of Business \& Management (COES\&RJ$J B M), 8(1), 1-19$.

Schumpeter, J. A. (1934). The theory of economic development.(reprinted in 1997).

Sefiani, Y. (2013). Factors for success in SMEs: a perspective from Tangier (Doctoral dissertation, University of Gloucestershire).

Sekaran, U., \& Bougie, R. (2016). Research methods for business: A skill building approach. John Wiley \& Sons.

Starr, J. A., \& MacMillan, I. C. (1990). Resource cooptation via social contracting: Resource acquisition strategies for new ventures. Strategic Management Journal, 11, 79-92.

Venkataraman, S. (1997). The distinctive domain of entrepreneurship research (Vol. 3, pp. 119-38). 
Walker, E. (2004). What success factors are important to small business owners? International Small Business Journal, 22(6), 577-594.

Witt, P. (2004). Entrepreneurs' networks and the success of start-ups. Entrepreneurship \& Regional Development, 16(5), 391-412.

Wolff, H. G., \& Moser, K. (2006). Entwicklung und validierung einer networkingskala. Diagnostica, 52(4), 161-180.

Wolff, H. G., \& Moser, K. (2009). Effects of networking on career success: a longitudinal study. Journal of Applied Psychology, 94(1), 196.

Zhao, L., \& Aram, J. D. (1995). Networking and growth of young technology-intensive ventures in China. Journal of business venturing, 10(5), 349-370.

Zhao, L., \& Jung, H. B. (2018). The winning personality. International Journal of Entrepreneurial Behavior \& Research, 24(2), 553-573.

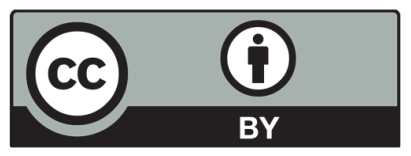

(C) 2020 by the authors; licensee Growing Science, Canada. This is an open access article distributed under the terms and conditions of the Creative Commons Attribution (CC-BY) license (http://creativecommons.org/licenses/by/4.0/). 